\title{
Trans-humanism as an Anthropological Problem
}

\author{
Igor V. Aksenov* \\ Department of Religious Education \\ and Catechesis of the Diocese of Vyborg \\ 1 Il'inskaia, Vyborg, Leningrad region, 188800, Russia
}

Received 07.12.2015, received in revised form 18.01.2016, accepted 07.02.2016

What is the individual? From the scientific point of view, the individual is a material object - a body. In Christian anthropology the individual is a created being, he is a material object - a body, and he is a person - subject, transcending the material world of objects at the same time. Philosophy gives different definitions of individual but in the mid-twentieth century the rejection of the human being, as a subject and as an existing being, was openly proclaimed for the first time by structuralism - the founder of trans-humanism. The aim of the philosophical concept of transhumanism is to liberate the human race from the inherent biological limitations. Modern scientific and technological progress with its opportunity to reformat the human nature almost reached this concept. The science came the most closely to the real opportunity of changing of the human nature in the area of application of modern biomedical technologies that today allow us not only to provide medical assistance in overcoming diseases and relieving suffering, but also directly control the human life from its beginning to its end. For example, modern assisted reproductive technologies in fact substitute the natural processes of child-bearing and are connected with different manipulations with a future life of an individual. Such anthropogenetic perspectives generate a range of social, ethical and theological issues. The same technological aspirations which are giving the chance to the person to influence on the world, reduce the person to the status of object which can be designed and generated at will; the concept of mind as machine is the same concept which allows us to imagine possibility to alter ourselves, and at the same time it interferes with that we fulfilled these new duties. So there is the question: could the ideas of trans-humanism turn out to be direct dehumanization of life?

Keywords: trans-humanism, individual, person, assisted reproductive technologies, ethics.

DOI: 10.17516/1997-1370-2016-9-3-678-686.

Research area: philosophical anthropology.

The understanding of individual

in Modern science, philosophical and Christian anthropology

There exists an essential distinction in understanding the individual between modern science, philosophical and Christian anthropology. From the scientific point of view, the human being remains to be considered as a representative of the biological species Homo sapiens of the hominid family of mammal order, though a complexly organized social being, whose behavior is determined

(C) Siberian Federal University. All rights reserved

* Corresponding author E-mail address: iaxenov@gmail.com 
with both biological and non-biological factors.

Secularization of scientific knowledge of the human being led to the result summarized by the famous psychologist of the Soviet period A.N. Leontyev in the following words: "We took the human being to pieces and learned to "compute" every one, but we are not able to collect the whole individual from them" (Leontyev 1975, p. 43). The human being as an object of scientific research had lost its integrity.

According to I. Kant, the central question of philosophy is: "What is the individual and what is his particular place in the whole unity of the world?" (Popkova, 2010, p. 4) - and that remains the main question. Every thinker and every philosophical trend gave his own definition of the man, but none of them become final because of not being universal.

N. V. Popkova whites: "Variety of human essence led to forming other notions, manifesting sides of his being. "Individual" is a human being, who possesses characteristics, common for the human race. "Individuality" is a human being, who possesses characteristics and capacities, differentiating him from the others; peculiarities of hereditary and acquired traits, character and mind, that bear a unique way of existence. "Person" is a human being, who influences actively upon the surrounding world according to his own individual capacities; self-consciousness and selfcontrol is intrinsic to him. So, if "individual" is a product of anthropogenesis, and "individuality" is an individual, who assimilates social norms, then "person" is an active figure, who chooses his unique course of life consciously" (Popkova, 2010, p. 5).

So, from the philosophical-anthropological point of view, the human being is born as an "individual" but only becomes a "person". First of all, Orthodox anthropology perceives in the human being God's creature, as Reverend John of Damascus said: "created by the God from visible and invisible nature according the image and likeness of Himself, He made the body from the earth, He gave him soul, gifted with mind and intellect, created by Divine breath (Being. 2:7, 1:26-27)" (Damaskin 2012, p. 138). So, the individual is a created being, he is a material object - body, and he is a person - subject, transcending the material world of objects at the same time. In other words, "individual" is both "what" and "who". "Corporeality of the human being is personalized and inspired... Body and flesh can't consider out of spirit, without personality or only materialistically" (Bogoslovskaia Antropologiia 2013, p. 46). The ontological base of the existence of the individual underlies an act of creation of Trinitarian God according to the image and likeness of Him (Being.1:26).

Philosophical anthropology also distinguished body, soul and spirit in the individual. As N. V. Popkova writes: " "body" is the object, which is common for people and animals; "soul" identifies the inner world of the individual, his own psyche; "spirit" is sometimes understood as an immortal kernel of personality, but in the secular understanding, "spirit" means stable foundations of the human personality, higher capacities of the individual" (Popkova, 2010, p. 5).

As M. Y. Dvoretskaia writes: "Until secular psychology deals with the human being in his integrity, considering all his natures, necessity in the interdisciplinary attitude doesn't arise. But as soon as physiologists have to resort to existential categories that require not only psychical, but also spiritual nature, insufficiency of materialistic understanding and empiric method of research become clearly apparent. It's category of "spirit" and its semantic content that determine the construction of interactive knowledge about the human being. But doctrine 
of the patristic psychology first of all is based on the idea of the spiritual nature of the human being. Furthermore, in contrast to scientific psychology, wherein the body produces the psyche, saints taught that the spirit creates the body. The spirit comes first to this world in order to "weave" the corporal organism, which in full measure corresponds to the life goal, for which the individual is born. Normative for the sacred fathers was the person in the unity of three natures: spiritual, psychic and bodily" (Dvoretskaia, 2015).

Indeed, our experience clearly shows us that the human being is both the subject and the object - the personality, and the nature. But, at the same time, we tend to perceive our personality as a part of our nature, as a rule, associated with our mental-bodily, so called cerebral activity. But, if it is so, then we will have to admit that the human personality is determined by its biochemical constitution, that heredity, that each of us receives from the first cells of our body the zygote - which carries in the diploid set of chromosomes; all the genetic characteristics of both parent organisms, having developed male and female gametes.

And in that case, the combination of the 46 paired chromosomes, formed by the merge of two haploids - which have 23 unpaired chromosomes - of the male and female gametes, should be understood "not as the realization and manifestation of the hypostatic otherness of the human person, but as its cause and constituted base... In other words, - how the modern Greek theologian Khristos Iannaras says, - we have to admit that the biological beginnings and functions, lying in the basis of bodily human life, determine and exhaust the fact of human existence as a whole, the hypostasis of the human subject..." (Iannaras Kh.).

But, man was originally created according to the image of Trinitarian God, which first of all was depicted in a personal form of his life. And such a conformity of man to God implies that "the human person is not a part of being human, just as the Persons of the Holy Trinity - not a part of being Divine" (Losskii, 1991, p. 91). Moreover, the person, as a possessor of the image of the Creator must also possess transcendence, intrinsic to the Original image in contrast to Nature, whereby the Divine image, or the human personality is not a part of his created spiritual-bodily or any other nature.

Thus, the human being as a whole doesn't reduce to his physical nature. According to the determination of V. N. Losskii, his personality "is irreducible to his nature". V. N. Losskii notices that our personality is "just irreducibility and isn't "something irreducible" or "something that causes a person to be irreducible to his nature", because we can't speak about something different, about "another nature", but only about someone who is different from his own nature, and who, containing within itself his nature, surpasses it and by his superiority gives the existence to the true human nature and who nevertheless doesn't exist by himself, beyond his nature" (Losskii, 1995, p. 114).

"A man is born as a person but in the same time he is invoked to become a personality in its wholeness and perfection. The perfection of the individual is not seen in his nature" (Bogoslovskaia Antropologiia, 2013, p. 47). In the theological understanding of the human personality, the personality "is irreducible to the nature, free, opened, unique and integral as indivisible and as having indestructible identity. Personality is the ontological basis of the human being, unknowable by objectified analytical methods, that creatively defines the image of being of his individualized nature and actualizes itself in communication, due to personal relationships" (Bogoslovskaia Antropologiia, 2013, p. 71). 


\section{Modern biomedical technologies and possibility of changing human nature}

As it has been already said, the scientifictechnical progress came the most closely to the real opportunity of changing of the human nature and increasing of life duration in the area of application of modern biomedical technologies, which permitus to talk about agenetically modified individual (Homo Genetically Transformed) as a modern state of reality of the practical application of the achievements of the scientific-technical progress. It is directly possible to make changes in human nature through genetic manipulations over the human embryos, which, by using the extracorporeal fertilization or cloning, could continue and finish their biological pre-natal development in the natural mother's medium or in the imitation of uterus in perspective.

But due to the fact, that modern assisted reproductive technologies are involved not only in production of human embryos but in their destruction also, they inevitably set before us two conjugated questions. The answer to one of them is impossible without the answer to another. The question of the "beginning of life" logically withdraws us from the realm of "objective" world and puts us face to face with the "subjective" reality of the one who began to live. And the answer to the question, when an embryo becomes a person, brings us back to the "beginning of life" of the embryo, because, as a well-known axiom of Aristotle says, there is no nature without a hypostasis.

"In the Helsinki Declaration of the World Medical Association says: "Interests and welfare of the individual should prevail over the interests of society and science". But how can we apply it to the research on human embryos, when the status of the embryo is not defined?" (Kurilo, 2003) as L. F. Kurilo rightly notices. Indeed, between all the variety of questions, arising during the consideration of assisted reproductive technology, the main question, both for the scientific and traditional Christian outlook, is one about the status of the human embryo. Who is he? Or what is $i t$ ? Early embryo is composed of blastomeres undifferentiated cells, possessing the property of totipotency, - is this the beginning of life itself or the beginning of life of a person with its unique personality? At what stage of embryo development can be described as a person, who has certain rights and first of all the right to life?

"Most of the experts participating in the discussion of this problem, - are sumed up by Kurilo L. F., - taking into account impossibility to solve the question about the status of the human embryo at the present time and about impossibility to stop the use of assisted reproductive technology..., adhere to a moderate position. According to it, in the base of lives beginning lies a nature of consistent biological processes, and protection of the human embryo relates to the degree of its development" (Kurilo, 1998).

Indeed, if the individual is reduced to his nature, then just its condition will determine the status of the human being. If the human being doesn't reduce to his biological nature, but manifests itself as a subject, through its own nature in energies, then one has to see in the first fertilized cell not a new combination of 46 chromosomes, which appears as a result of fusion of two gametes, but the one who is invoked from the nothingness into the being by the creative Word of God, with his own unique way to come.

However, when we claim the human dignity for an embryo, we still say nothing about the attitude to the fact of "construction" and "giving" life beyond relationships, the marital love conjugation in "one flesh" (Being, 2:24). Indeed, until recent time treatment of diseases meant rendering assistance or removing the barriers of the flow of natural processes inside the human organism. But modern assisted reproductive 
technologies in fact substitute the natural processes of child-bearing and are connected with different manipulations with a future life of an individual.

\section{Theological, social and ethical issues of using modern assisted reproductive technologies}

So, it causes a question about acceptability of these ways of "giving" life irrelatively to the destruction of "superfluous" embryos. Moreover, the development of the anthropogenesis already permits to intervene in the genetic code, which sooner or later will lead to modifications in the human nature. In other words, as D. A. Beliaev writes, "there arises a possibility of genetic programming of human qualities through the modification of the structure of his DNA, in the course of which the exclusion of "harmful" genes and the adding of "helpful" genes are planned. As a result it is presumed, that the individual will get rid from the most of inherited illnesses and "harmful" predispositions; lifespan will appreciably increase; and it will be possible to modify genes in order to regenerate biologically, to exert a direct influence on general morphology, physiology, metabolism and even on psychological characteristics of the human being" (Beliaev, 2014).

In the Christian anthropology the image of the human family was never seen as the only one of possible primary structures of the society which depends on its development level. Metropolitan Hilarion (Alfeev), speaking about the Divine image of the human being, refers to the point of view of St. Gregory of Nyssa in his article "Some approximately meaning "according to the Divine image" ". In the first family of the first man, consisted of Adam, Eva and their son - St. Gregory of Nyssa saw the image of Father, Spirit and Father's Son. "God creates not only one person, an individual, a lonely self-closed monad, but "the man and the woman" and ordered to them "to reproduce and propagate themselves" (see: Being 1:27-28). As God is united in three Hypostases, the man is created as a multi-hypostasis being" (Ilarion (Alfeev), 2012, p. 507).

Another challenge that arises relatively to assisted reproductive technology use, is the problem of significance of the interpersonal relationships in an act of marital conjunction while conception of a child, because assisted reproductive technologies mean the substitution of the dialogical form of the interpersonal communication, arising between two human hypostases in their bodily conjunction, by various technologies and technical means. The problem is enough difficult to deal with and substantiate, because modern science can't tell anything about the metaphysics of conception, though knows much about its physical aspects. I tried to investigate this problem in the article "The Divine image of the human being and modern assisted reproductive technologies". So here in order not to repeat and to deepen in the theology of this problem, I just cite the final document of the International Theological Commission in Rome 2000-2002: “...marriage constitutes an elevated form of the communion between human persons and one of the best analogies of the Trinitarian life. When a man and a woman unite their bodies and spirits in an attitude of total openness and self-giving, they form a new image of God. Their union as one flesh does not correspond simply to a biological necessity, but to the intention of the Creator in leading them to share the happiness of being made in his image. The Christian tradition speaks of marriage as an eminent way of sanctity" (Communion and Stewardship, paragraph 38). "Persons created in the image of God are bodily beings whose identity as male or female orders them to a special kind of communion with one another ..., the nuptial meaning of the body finds 
its realization in the human intimacy and love that mirror the communion of the Blessed Trinity whose mutual love is poured out in creation and redemption" (Communion and Stewardship, paragraph 40).

Thus, even bodily wish to possess beauty and kindness of the other individual in interpersonal free and honest enjoyment in mutual self-sacrifices can't help bearing the cordiality of love, arising from the presence of "eternal Thou" (Zavershinsky), which, according Martin Buber, "constitutes a mutuality, arising again and again, such as can subsist only between persons" (Zavershinsky) and together with I and Thou of beloved will originate being of a new personality.

According this, we are forced to recognize that any assisted reproductive technologies that don't help to reach conception in the real act of matrimonial conjunction, but substitute its dialogical form of interpersonal communication in bodily unity by different technical means, falls short of personal relations of love according to the Divine image.

Such anthropogenetic perspectives, as D. A. Beliaev writes, causes a set of philosophical challenges. "First of all, genetic investigations directed to the improvement of the human nature are considered as a part of eugenics, having been compromised in the $20^{\text {th }}$ century from the humanistic point of view. Secondly, the challenge is in the absence of consensus about the proper or positive qualities to approve genetically. Thirdly, the possibility of interference in the genetic matrix of the individual and perspectives of cloning actualizes a number of bioethical problems... Also,... the identification of genetic determinants leads to an existential-ontological desacralization of the person who loses the aura of exclusivity; destined to be likened to a "biological computer" in the public consciousness. Besides, the possibility of genetic decoding of the individual put in a new way the question about his freedom, reality/ illusion of his behavior and existential choice" (Beliaev, 2014).

In the modern world the social benefit turned to be closely connected with a notion of "progress". The progress became to consider an indisputable benefit and, moreover, the subject of faith and esperance of the modern mankind, opposed to the New Testament. But, as I. S. Aksakov truly noticed: "Progress that negates God and Jesus Christ, finally became regress, civilization comes to wildness, freedom turns to despotism and slavery. Having lost his Divine image, an individual will inevitably lose... his human image, aspiring to his animal aspect" (Osipov, 2014, p. 217).

Paradoxically, modern technologies providing reproduction of the human life is nowadays coming to a devaluation. As E. N. Gnatik writes, "the creation of the "additional" zygotes and their following annihilation is a condition of the artificial impregnation. Negative results of prenatal diagnostics is a reason for the artificial abortion of life. Fetal therapy reduce human embryos... to pharmaceutical "material"... The development of cloning technology also can cause a menace to a human dignity... depriving the human genome protection from the outside intervention" (Gnatik, 2007, p. 71).

Obviously, a great danger exists that intervention into the human genome, so called genetic engineering, will come across "the threat of transformation not only human body,... but the features of personality, the peculiarities of individual consciousness, emotional mood and spiritual reality" (Gnatik, 2007, p. 74-75). We can confront a result that F. Fukuiama warns us about: "We would mix the human genome with genes of so many different spices, that we won't clear understand what the man is" (Fukuiama, 2004, p. 351). 


\section{Conclusion}

Thus, attentively investigated, the ideas of trans-humanism turned out to be direct dehumanization of life. Why did it happen? Along with I. S. Aksakov, the adequate answer to this question V. A. Kutyrev gives: "Fundamental historical turn and the underlying philosophical foundation for the emergence of trans-humanism is the transformation of substantialist to a functionalistic worldview paradigm, and then to relativist progressing to a constructivist one. The rejection of metaphysics with its necessary ontologism and beginning from Kant gnoseologization of philosophy. The rejection of the human being, as a subject and as an existing being, was openly proclaimed for the first time by structuralism in the mid-twentieth century. However, it seemed some kind of theoretical ploy. Philosophical structuralism and, more broadly or culturologically, postmodernism declared "the long haul" about the death of a personality and put the ultimate goal in achieving it. Trans-humanism is a component, a condition and a result of postmodernism, its ensuing consequence" (Kutyrev, 2010, p. 8).

Orthodox Christianity on no account rejects scientific knowledge, but suggests to "the absolutism of empirical sciences" (Solovyev, 1989, p. 203) natural moral boundaries, "recognizing that above the personality and external nature, there's the other, unconditional, Divine world, infinitely more valid, rich, alive, than the world of illusory surface phenomena" (Solovyev 1989, p. 203). Therefore, in the basic social concept of the Russian Orthodox Church in relation to the use of assisted reproductive technologies, it is explicitly stated: "the Church cannot regard as morally justified the ways to childbirth incompatible with the intention of the Creator of life" (Osnovy sotsialnoi kontseptsii Russkoi Pravoslavnoi Tserkvi).

\section{References}

Beliaev, D.A. The Perspective Anthropological Models of the Post-human: the Transformation of the Human Nature and Superhuman Attributes [Perspektivnye antropologicheskie modeli postcheloveka: transformatsiia chelovecheskoi prirody i sverkhchelovecheskaia atributika]. Global'noe budushchee 2045: Antropologicheskii krizis. Konvergentnye tekhnologii. Transgumanisticheskie proekty: Materialy Pervoi Vserossiiskoi konferentsii [Global future 2045: the Anthropological Crisis. Convergent Technologies. Trans-humanist Projects: the First all-Russian conference], Belgorod, 2013. Ed. by Dubrovskii, D.I., Klimova, S.M. Moscow: "Kanon+" ROOI "Reabilitatsiia”, 2014.

Bogoslovskaia Antropologiia. Russko-pravoslavnyi - rimsko-katolicheskii slovar' [Theological Anthropology. Russian-Orthodox - Roman-Catholic Dictionary]. Ed. by Archpriest Andrei Lorgus, Shtubenraukh, B. Moscow: Palomnik; Nikeia, 2013. 736 p.

Communion and Stewardship: Human Persons Created in the Image of God. International Theological Commission, Rome, 2000-2002. Available at: URL: http://www.philvaz.com/apologetics/ p80.htm (accessed 2 November 2015)

Damaskin Ioann, prepodobnyi [Reverend John of Damascus]. Tochnoe izlozhenie Pravoslavnoi very [Exact Exposition of the Orthodox Faith]. Moscow: Sibirskaia Blagozvonnitsa, 2012. 476 p.

Dvoretskaia, M.Ia. Religious-philosophical Teaching of the Holy Fathers about "the Spirit" as the Basis of Integrative Psychological Conception of the Individual [Religiozno-filosofskoe uchenie sviatykh ottsov o "dukhe", kak osnovanie integrativnoi psikhologicheskoi kontseptsii cheloveka]. Sbornik dokladov 2013-2014. I i II Arkhangel'skie eparkhial'nye obrazovatel'nye chteniia [Collection 
of reports 2013-2014. Ist and IId Archangel Diocesan Educational Readings], Vyborg, 2013-2014. St.Petersburg - Vyborg: Izdatel'stvo RKHGA, 2015. pp. 10-19.

Fukuiama, F. Nashe postchelovecheskoe budushchee [Our Post-human Future]. Moscow, 2004.

Gnatik, E.N. (2007). The Role of the Axiological Approach to Anthropogenesis and Genetic Engineering [Rol' tsennostnogo podkhoda $\mathrm{v}$ antropogenetike i geneticheskoi inzhenerii]. Voprosy filosofii [Problems of Philosophy], 8, 70-78.

Iannaras, Kh. Vera Tserkvi. Chelovek. Iazyk nauki [The Faith of Church. The Human Being. Language of Science] Available at: http://azbyka.ru/vera-cerkvi.shtml\#n39 (accessed 2 November 2015)

Ilarion (Alfeev), mitropolit [Metropolitan Hilarion (Alfeev)]. Pravoslavie: $v 2 t$. [Orthodoxy: in 2 vol.]. Moscow: Izdatel'stvo Sretenskogo monastyria, 2012. 1 vol., 864 p.

Kurilo, L.F. (2003). Ethical and Legal Aspects of Using Human Stem Cells [Etiko-pravovye aspekty ispol'zovaniia stvolovykh kletok cheloveka]. Chelovek [The Individual], 3. Available at: http:// vivovoco.astronet.ru/VV/PAPERS/MEN/CELLS.HTM (accessed 2 November 2015)

Kurilo, L.F. (1998). Development of the Human Embryo and some Moral and Ethical Problems of Auxiliary Reproduction Techniques [Razvitie embriona cheloveka i nekotorye moral'no-eticheskie problemy metodov vspomogatel'noi reproduktsii]. Problemy reproduktsii [Problems of Reproduction], 3. Available at: http://www.rusmedserv.com/problreprod/1998g/3/article_590.html (accessed 2 November 2015)

Kutyrev, V.A. Filosofiia transgumanizma [The Philosophy of Trans-humanism]. Nizhnii Novgorod: Nizhegorodskii Universitet, 2010. 84 p.

Leontyev, A.N. Deiatel'nost'. Soznanie. Lichnost' [Activity. Consciousness. Individual]. Moscow: Politizdat, 1975.304 p.

Losskii, V.N. Bogoslovskoe poniatie chelovecheskoi lichnosti. Po obrazu i podobiiu [The Theological Notion of the Human Personality. According the Divine Image and Likeness]. Moscow, 1995.

Losskii, V.N. Ocherk misticheskogo bogosloviia Vostochnoi Tserkvi [Essay about the Mystical Theology of the Eastern Church]. Moscow: Tsentr "SEI", 1991. 289 p.

Osipov, A.I. Put' razuma v poiskakh istiny [The Path of Reason in the Searching of Truth]. Moscow: Izdatel'stvo Sretenskogo monastyria, 2014. 496 p.

Osnovy sotsial'noi kontseptsii Russkoi Pravoslavnoi Tserkvi: Gl. XII.4. [Bases of the Social Concept of the Russian Orthodox Church. CH. XII.4] Available at: http://www.patriarchia.ru/db/ text/141422 (accessed 2 November 2015).

Popkova, N.V. Vvedenie v filosofskuiu antropologiiu [Leading into the philosophical anthropology]. Moscow: Knizhnyi dom “LIBROCOM”, 2010. 344 p.

Solovyev, V.S. (1989) Three Powers [Tri cily]. Novyi mir [New world], 1.

Zavershinsky George, Rev. Theology of dialogue: dialogue as a modus of human existence. International Orthodox-Catholic Conference "Give a Soul to Europe. The Mission and Responsibility of the Churches", Vienna, May 3-5, 2006. Available at: http://www.interfax-religion. com/?act=documents\&div=67 (accessed 2 November 2015). 


\section{Трансгуманизм}

\section{как антропологическая проблема}

И.В. Аксёнов

Отдел религиозного образования и катехизаџии Выборгской епархии Россия, 188800, Ленинградская область, г. Выборг, ул. Ильинская, 1

Что есть человек? Наука рассматривает человека как материальный объект - тело. В христианской антропологии человек - это сотворенное существо, одновременно и объект - тело, и личность - субъект, трансиендентный миру объектов. Философия по-разному определяет человека, но в середине XX века впервые отказ от человека как субъекта и как сущего провозгласил структурализм, родоначальник трансгуманизма. Философская концепция трансгуманизма ставит своей целью освобождение человека от присущих ему биологических ограничений. Современный научно-технический прогресс c его возможностью переформатирования человека вплотную приблизился $к$ этой концепции. Наиболее близко к реальной возможности изменения человеческой природы наука подошла в области применения биомедииинских технологий, которые уже сегодня позволяют не только оказывать врачебную помощь в преодолении болезней и облегчении страданий, но и непосредственно управлять самой жизнью человека от её начала и до её завершения. Например, современные вспомогательные репродуктивные технологии фактически подменяют естественные прочессы деторождения различными технологиями и сопряжены с различными манипулящиями в отношении будущей человеческой жизни. Такие антропогенетические перспективы порождают иелый ряд социальных, этических и богословских вопросов. Одни и те же технологические устремления, дающие человеку возможность воздействовать на мир, сводят человека до статуса объекта, который может быть спроектирован и сформирован по желанию; концепция разума как машинь является той же самой концепиией, которая позволяет нам воображать возможность переделать нас самих, и в то же самое время она препятствует тому, чтобы мы, потеряв свою субъектность, могли этого достичь. Возникает вопрос: не обернутся ли идеи трансгуманизма откровенной дегуманизаџией жизни?

Ключевые слова: трансгуманизм, человек, личность, вспомогательные репродуктивные технологии, этика.

Научная специальность: 09.00.13 - философская антропология. 